\title{
HUBUNGAN ANTARA KADAR GULA DARAH BAYI BARU LAHIR DENGAN IBU HAMIL YANG MENGALAMI OBESITAS
}

\author{
${ }^{1}$ Bella Rumangkang \\ ${ }^{2}$ Rocky Wilar \\ ${ }^{2}$ Vivekenanda Pateda
}

\author{
${ }^{1}$ Kandidat Skripsi Fakultas Kedokteran Universitas Sam Ratulangi Manado \\ ${ }^{2}$ Bagian Ilmu Kesehatan Anak Fakultas Kedokteran Universitas Sam Ratulangi Manado \\ Email: bellarumangkang12261@gmail.com
}

\begin{abstract}
Nowadays, obesity has gotten serious concerns because of the increasing number of sufferers including the number of obese people in pregnant women. The number of obese pregnant women has increased by approximately $18.5 \%$ to $38.3 \%$. Obesity is a condition that indicates an imbalance between the height and the weight due to the fat tissue in the body resulting in weight excess beyond the ideal weight. The obesity is nearly always harmful to the mother and fetus, and it can come down to the infants. While in the womb, the fetus receives all the energy and glucose which are obtained from the mother. After the birth, the amount of glucose, that is stored in the baby's body in the form of liver and muscle glycogen, is only enough to supply the needs of the baby for a few hours, so the baby's blood sugar levels decreases and hypoglycemic occurs.
\end{abstract}

Objectives: This research intends to determine correlation between the blood sugar levels of newborn babies and pregnant women who experience obesity.

Material Methods: This research is a prospective analytical study conducted in pregnant women through direct data collection by measuring the weight and height, and the measurement of the blood sugar levels in the newborn babies in RSUP Prof. Dr. R. D Kandou Manado, RS R.W Monginsidi Teling Manado, RSU Pancaran Kasih Manado, and Puskesmas Bahu Manado during the months of November 2015 to January 2016.

Result: The study result of the 38 respondents found out that pregnant women who are obese to the obese category I as many as 30 people (78.9\%), 5 people (13.2\%) in obese II , and 3 people $(7.9 \%)$ in obese III. The distribution according to the frequency of food consumption of mothers in which 36 of them $(94.7 \%)$ with a frequency of $\geq 3 \mathrm{x}$ meals a day and $2(5.3 \%)$ with a food frequency $\leq 3$ times a day. The distribution according to the activity of the mother that the majority of mild activity as many as 31 people (81.6\%), 4 people (10.5\%) having tough activities, and 3 people (7.9\%) having light activities. The distribution according to the mother's knowledge about obesity there were 14 people (36.8\%) who knew about obesity and there were 24 people (63.2\%) who did not know about obesity. According to the mother's knowledge on maternal blood sugar, they all (100\%) knew. Based on the distribution according to the sex of a newborn babies, there were 23 male infants (60.5\%) and 15 female infants (39.5\%). According to the baby's weight distribution; there were 14 infants (36.8\%) with a body weight between 3100 to 3500 grams, 13 infants (34.2\%) with a body weight between 2,500 to 3,000 grams, and 11 infants (29\%) by weight between 3600 to 4000 grams. The distribution according to the blood sugar levels that the majority of newborn infants with low blood sugar levels were between $15-20 \mathrm{mg} / \mathrm{dL}$ totaling 21 infants (55.3\%), blood sugar levels between 26-30 mg / dL were 9 infants (23.7 \%), while blood sugar levels between 21-25 mg / dL and 36-40 mg / dL obtained a similar number that is 4 infants $(10.5 \%)$. 
Conclusion: The research result which was done has two different conclusions. Based on the theory, there was $\mathrm{H} 1$ which has relationship between all pregnant women who are obese and low blood sugar levels in the newborn babies. Based on the statistical test, there was $\mathrm{HO}$ which has no significant correlation between blood sugar levels of newborn babies and mothers who are obese.

Keywords: obesity, pregnant women, blood sugar levels, newborn babies, hypoglycemia.

\begin{abstract}
Abstrak: Saat ini obesitas mendapat perhatian yang serius karena jumlah penderitanya yang semakin meningkat termasuk jumlah penderita obesitas pada ibu hamil. Jumlah penderita obesitas pada ibu hamil meningkat sekitar 18,5\% sampai dengan 38,3\%. Obesitas merupakan keadaan yang menunjukkan ketidakseimbangan antara tinggi dan berat badan akibat jaringan lemak dalam tubuh sehingga terjadi kelebihan berat badan yang melampaui berat badan ideal. Obesitas hampir selalu berbahaya bagi ibu dan janinnya, dan dapat menurun pada bayi. Selama dalam kandungan, janin memperoleh semua energi dan glukosa yang didapat dari ibu. Setelah kelahiran, jumlah glukosa yang disimpan dalam tubuh bayi dalam bentuk glikogen hati dan otot hanya cukup untuk menyuplai kebutuhan bayi beberapa jam saja, sehingga kadar gula darah bayi menurun dan terjadi hipoglikemia.
\end{abstract}

Tujuan: Penelitian ini bertujuan untuk mengetahui hubungan antara kadar gula darah bayi baru lahir dengan ibu hamil yang mengalami obeistas.

Metode Penelitian: Penelitian ini merupakan studi analitik prospektif yang dilakukan pada ibu hamil melalui pengambilan data secara langsung dengan pengukuran berat badan dan tinggi badan dan pengukuran kadar gula darah pada bayi baru lahir di RSUP Prof. Dr. R. D Kandou Manado, RS R.W Monginsidi Teling Manado, RSU Pancaran Kasih Manado, dan Puskesmas Bahu Manado selama bulan November sampai Januari 2016.

Hasil: Hasil peneilitian dari 38 responden di dapatkan ibu hamil yang mengalami obesitas dengan kategori obese I sebanyak 30 orang (78,9\%), obese II sebanyak 5 orang (13,2\%), dan obese III sebanyak 3 orang (7,9\%). Distribusi menurut frekuensi konsumsi makanan dari ibu diperoleh 36 orang $(94,7 \%)$ dengan frekuensi makanan $\geq 3 \mathrm{x}$ sehari dan 2 orang $(5,3 \%)$ dengan frekuensi makanan $\leq 3 \mathrm{x}$ sehari. Distribusi menurut aktivitas ibu bahwa mayoritas beraktivitas ringan sebanyak 31 orang $(81,6 \%)$, aktivitas berat didapatkan 4 orang $(10,5 \%)$ dan aktivitas ringan didapatkan 3 orang (7,9\%). Distribusi menurut pengetahuan ibu tentang obesitas terdapat 14 orang $(36,8 \%)$ yang mengetahui tentang obesitas dan terdapat 24 orang $(63,2 \%)$ yang tidak mengetahui tentang obesitas. Menurut pengetahuan ibu tentang gula darah didapatkan semua ibu (100\%) mengetahuinya. Berdasarkan distribusi menurut jenis kelamin bayi baru lahir didapatkan laki-laki berjumlah 23 bayi (60,5\%) dan perempuan berjumlah 15 bayi (39,5\%). Distribusi menurut berat badan bayi didapatkan 14 bayi (36,8\%) dengan berat badan antara 3100 sampai 3500 gram, 13 bayi (34,2\%) dengan berat badan antara 2500 sampai 3000 gram, dan 11 bayi (29\%) dengan berat badan antara 3600 sampai 4000 gram. Distribusi menurut kadar gula darah bayi baru lahir bahwa mayoritas bayi dengan kadar gula darah terendah antara $15-20 \mathrm{mg} / \mathrm{dL}$ berjumlah 21 bayi (55,3\%), kadar gula darah antara 26 - $30 \mathrm{mg} / \mathrm{dL}$ berjumlah 9 bayi (23,7\%), sedangkan kadar gula darah antara $21-25 \mathrm{mg} / \mathrm{dL}$ dan $36-40 \mathrm{mg} / \mathrm{dL}$ diperoleh jumlah yang serupa yaitu 4 bayi $(10,5 \%)$.

Simpulan: Dari hasil penelitian yang dilakukan diperoleh 2 simpulan yang berbeda. Berdasarkan teori, didapatkan $\mathrm{H} 1$ yaitu ada hubungan antara semua ibu hamil yang mengalami obesitas dengan kadar gula darah yang rendah pada bayi baru lahir. Berdasarkan uji statiska, didapatkan H0 yaitu tidak terdapat hubungan yang bermakna antara kadar gula darah bayi baru lahir dengan ibu yang mengalami obesitas.

Kata kunci: obesitas, ibu hamil, kadar gula darah, bayi baru lahir, hipoglikemia.

Kadar gula darah atau glukosa darah didefinisikan gula yang terdapat dalam darah yang terbentuk dari karbohidrat dalam makanan dan disimpan sebagai glikogen di hati dan otot rangka. Peningkatan glukosa secara abnormal di 
dalam darah disebut hiperglikemia, sedangkan penurunan glukosa dalam darah secara abnormal disebut hipoglikemia. ${ }^{1}$

Kadar gula darah bayi baru lahir pada umumnya normal, namun tergantung pada beberapa faktor dari ibu pada masa kehamilan. Salah satu faktor yang memengaruhi kadar gula darah bayi baru lahir yaitu makanan dari ibu. Jika ibu mengkonsumsi makanan yang berlebihan, dampaknya adalah terjadinya obesitas. ${ }^{2,3}$

Obesitas merupakan suatu penyakit multifaktorial, yang terjadi akibat penimbunan jaringan lemak berlebihan, sehingga dapat mengganggu kesehatan. Seseorang disebut mengalami obesitas apabila berat badan naik melampaui 20\% dari berat badan normal. Pada ibu hamil, obesitas adalah keadaan yang menunjukkan ketidakseimbangan antara tinggi dan berat badan yang melampaui ukuran ideal. ${ }^{4}$

WHO dan National Institues of Health (NIH) mendefinisikan obesitas sebagai keadaan dimana Indeks Massa Tubuh $\left(\right.$ IMT) $\geq 30 \mathrm{~kg} / \mathrm{m}^{2}$. Obesitas dibagi lagi menjadi obese I dengan IMT 30,0 34,9, obese II dengan IMT 35 - 39,9, dan obese III dengan IMT $\geq 40 \mathrm{~kg} / \mathrm{m}^{2}$.5,6

Banyak faktor yang berperan terhadap terjadinya obesitas, diantaranya faktor lingkungan, gaya hidup, genetik, dan sosioekonomi. Obesitas merupakan suatu keadaan gangguan keseimbangan antara asupan kalori dan penggunaanya. Sehingga, obesitas meningkatkan risiko beberapa kejadian gangguan kesehatan, salah satunya gangguan metabolisme glukosa. Dengan demikian, obesitas erat kaitannya dengan kadar gula dalam darah.

Salah satu dampak negatif obesitas adalah resistensi insulin, yaitu ketidakmampuan insulin untuk menghasilkan fungsi biologik secara normal (menurunnya sensivitas insulin), ditandai dengan peningkatan insulin puasa yang kemudian akan menyebabkan terjadinya peningkatan kadar gula darah. ${ }^{7}$

Dalam sebuah studi kasus-kontrol, Lashen mendapatkan bahwa obesitas hampir selalu berbahaya bagi ibu dan janinnya. Selain itu, faktor genetik obesitas dapat menurun pada bayi. sebuah studi kasus-kontrol, Lashen mendapatkan bahwa obesitas hampir selalu berbahaya bagi ibu dan janinnya. Selain itu, faktor genetik obesitas dapat menurun pada bayi. ${ }^{5}$

Berdasarkan uraian di atas penulis tertarik melakukan penelitian untuk mengetahui hubungan antara kadar gula darah bayi baru lahir dengan ibu hamil yang mengalami obesitas.

\section{METODE PENELITIAN}

Penelitian analitik prospektif, dilakukan pada ibu hamil melalui pengambilan data secara langsung dengan pengukuran berat badan dan tinggi badan dan pengukuran kadar gula darah pada bayi baru lahir di RSUP Prof. Dr. R. D Kandou Manado, RS R.W Monginsidi Teling Manado, RSU Pancaran Kasih Manado, dan Puskesmas Bahu Manado selama bulan November sampai Januari 2016. Data diolah dengan program IBM SPSS statistik 22. Hubungan kedua variabel menggunakan uji korealsi pearson.

\section{HASIL PENELITIAN}

Berdasarkan penelitian di RSUP Prof. Dr. R. D Kandou Manado, RS R.W Monginsidi Teling Manado, RSU Pancaran Kasih Manado, dan Puskesmas Bahu Manado selama bulan November sampai Januari 2016, diperoleh jumlah pasien dengan kriteria inklusi yaitu 38 sampel. Tabel 1 memperlihatkan distribusi klasifikasi berat badan ibu menurut IMT. Distribusi termasuk dalam kategori obese I sebanyak 30 orang $(78,9 \%)$, obese II sebanyak 5 orang (13,2\%), dan obese III sebanyak 3 orang (7,9\%). Tabel 2 memperlihatkan 
distribusi menurut frekuensi konsumsi makanan dari ibu. Diperoleh data ibu hamil yang obesitas mengkonsumsi makanan dengan frekuensi $\geq 3 \mathrm{x}$ sehari sebanyak 36 orang (94,7\%), sedangkan yang mengkonsumsi makanan $\leq 3 \mathrm{x}$ sehari hanya 2 orang (5,3\%). Tabel 3 memperlihatkan bahwa mayoritas ibu hamil yang obesitas dengan aktivitas sehari-hari yaitu aktivitas

Tabel 1. Distribusi klasifikasi berat badan ibu menurut IMT

\begin{tabular}{lll}
\hline Kategori & $\mathrm{n}$ & $\%$ \\
\hline Obese I & 30 & 78,9 \\
Obese II & 5 & 13,2 \\
Obese III & 3 & 7,9 \\
Total & 38 & 100 \\
\hline
\end{tabular}

Tabel 2. Distribusi frekuensi konsumsi makanan dari ibu

\begin{tabular}{lll}
\hline Frekuensi konsumsi & $\mathrm{n}$ & $\%$ \\
\hline$\leq$ 3x sehari & 2 & 5,3 \\
$\geq$ 3x sehari & 36 & 94,7 \\
Total & 38 & 100 \\
\hline
\end{tabular}

Tabel 3. Distribusi aktivitas dari ibu

\begin{tabular}{lll}
\hline Aktivitas & $\mathrm{n}$ & $\%$ \\
\hline Aktivitas Ringan & 3 & 7,9 \\
Aktivitas Sedang & 31 & 81,6 \\
Aktivitas Berat & 4 & 10,5 \\
Total & 100 & 100 \\
\hline
\end{tabular}

Tabel 4. Distribusi menurut pengetahuan ibu tentang obesitas

\begin{tabular}{lll}
\hline Pengetahuan Obesitas & $\mathrm{n}$ & $\%$ \\
\hline Ya & 14 & 36,8 \\
Tidak & 24 & 63,2 \\
Total & 38 & 100 \\
\hline
\end{tabular}

ringan. Tabel 4 terdapat 14 orang (36,8\%) yang mengetahui tentang obesitas dan terdapat 24 orang $(63,2 \%)$ yang tidak mengetahui obesitas. Tabel 5 memperlihatkan bahwa semua ibu hamil (100\%) mengetahui pengetahuan tentang gula darah.

Tabel 5. Distribusi menurut pengetahuan ibu tentang gula darah

\begin{tabular}{lll}
\hline Pengetahuan Gula Darah & $\mathrm{n}$ & $\%$ \\
\hline Ya & 38 & 100 \\
Tidak & 0 & 0 \\
Total & 38 & 100 \\
\hline
\end{tabular}

Tabel 6 memperlihatkan distribusi bayi baru lahir menurut jenis kelamin, didapatkan jumlah laki-laki 23 bayi (60,5\%), sedangkan perempuan 15 bayi (39,5\%). Tabel 7 memperlihatkan distribusi menurut berat badan bayi baru lahir, didapatkan berat badan antara 2500 - 3000 gram sebanyak 13 bayi, berat badan 3100 3500 sebanyak 14 bayi, dan berat badan antara 3600 - 4000 sebanyak 11 bayi. Tabel 8 distribusi menurut kadar gula darah bayi baru lahir, didapatkan bahwa mayoritas dengan kadar gula darah terendah antara 15 - $20 \mathrm{mg} / \mathrm{dL}$ sebanyak 21 bayi (55,3\%), kadar gula darah antara 26 $30 \mathrm{mg} / \mathrm{dL}$ berjumlah 9 bayi (23,7\%), sedangkan pada bayi dengan kadar gula darah antara 21 - $25 \mathrm{mg} / \mathrm{dL}$ dan $36-40$ $\mathrm{mg} / \mathrm{dL}$ diperoleh jumlah serupa yaitu 4 bayi $(10,5 \%)$.

Tabel 6. Distribusi jenis kelamin bayi baru lahir

\begin{tabular}{lll}
\hline Jenis Kelamin & $\mathrm{n}$ & $\%$ \\
\hline Laki-laki & 23 & 60,5 \\
Perempuan & 15 & 39,5 \\
Total & 38 & 100 \\
\hline
\end{tabular}


Tabel 7. Distribusi berat badan bayi baru lahir

\begin{tabular}{lll}
\hline Berat badan (gr) & $\mathrm{n}$ & $\%$ \\
\hline $2500-3000$ & 13 & 34,2 \\
$3100-3500$ & 14 & 36,8 \\
$3600-4000$ & 11 & 29 \\
Total & 38 & 100 \\
\hline
\end{tabular}

Tabel 8. Distribusi kadar gula darah bayi baru lahir

\begin{tabular}{lll}
\hline $\begin{array}{l}\text { Kadar gula darah } \\
(\mathrm{mg} / \mathrm{dL})\end{array}$ & $\mathrm{n}$ & $\%$ \\
\hline $15-20$ & 21 & 55,3 \\
$21-25$ & 4 & 10,5 \\
$26-30$ & 9 & 23,7 \\
$31-35$ & 0 & 0 \\
$36-40$ & 4 & 10,5 \\
$41-45$ & 0 & 0 \\
\hline
\end{tabular}

Tabel 9. Analisis bivariat kedua variabel

\begin{tabular}{lc}
\hline \multicolumn{2}{c}{ Hubungan IMT dan kadar gula darah } \\
\hline IMT & Kadar gula darah \\
Pearson Correlation & -.239 \\
Sig. (1-tailed) & .074 \\
$\mathrm{~N}$ & 38 \\
\hline *diuji dengan uji koefisien korelasi pearson
\end{tabular}

Hubungan antara variabel tersebut diperoleh $r=-0,0239$ dan berdasarkan nilai signifikan (p) yaitu 0,074 dengan nilai $\alpha=$ 0,05 , dimana nilai $\mathrm{p}>0,05$, sehingga hasil ini menyatakan ada hubungan namun tidak bermakna secara statistika antara kedua variabel.

\section{PEMBAHASAN}

Penelitian ini dilakukan pada ibu hamil yang mengalami obesitas dengan bayi baru lahir yang memiliki kadar gula darah rendah (hipoglikemia) di RSUP Prof. Dr. R. D. Kandou Manado, RS R.W Monginsidi Teling Manado, RSU Pancaran Kasih Manado, dan Puskesmas Bahu Manado selama bulan November 2015 sampai Januari 2016. Diperoleh jumlah sampel dengan kriteria inklusi yaitu 38 bayi.
Obesitas merupakan keadaan dengan akumulasi lemak yang tidak normal atau berlebihan di jaringan adiposa sehingga dapat menggangu kesehatan. Obesitas pada ibu hamil adalah kelebihan berat badan dengan IMT $>30 \mathrm{~kg} / \mathrm{m}^{2}$. Ibu hamil yang mengalami obesitas dapat dipegaruhi oleh makanan yang berlebihan dan berisiko mengalami masalah pada masa kehamilan. $^{4,5}$

Saat setelah makan terjadi peningkatan kadar gula darah yang merangsang pankreas menghasilkan menghasilkan insulin untuk mencegah kenaikan kadar gula darah lebih lanjut. Insulin memasukkan gula ke dalam sel sehingga bisa menghasilkan energi atau disimpan sebagai cadangan energi. Insulin berperan dalam mengatur glukosa darah. Namun, karena beberapa sebab, kerja insulin dapat mengalami gangguan. Resistensi insulin merupakan kondisi dimana ketika jumlah insulin yang diproduksi memadai, tetapi tidak mampu mengontrol kadar gula didalam darah dalam batas normal. Kondisi semacam ini dijumpai pada ibu haml yang mengalami obesitas, dimana terjadi hiperglikemia karena pola hidup yang tidak seimbang antara pemakaian dan pengeluaran terhadap energi, sehingga berdampak pada janin karena kadar gula darah janin bergantung pada ibu yang ditransfer melalui glukosa. ${ }^{8}$

Berdasarkan hasil penelitian pada ibu hamil, terdapat 30 orang (78,9\%) yang termasuk kategori obese I, 5 orang $(13,2 \%)$ termasuk kategori obese II, dan 3 orang $(7,9 \%)$ termasuk kategori obese III. Melalui kuesioner, pada variabel frekuensi konsumsi makanan ibu hamil didapatkan mayoritas mengkonsumsi makanan $\geq 3 \mathrm{x}$ sehari sebanyak 36 orang (94,7\%). Menurut artikel dari American Journal of Lifestyle Medicine, faktor yang berperan penting penyebab obesitas yaitu peningkatan konsumsi frekuensi makan. ${ }^{9}$ Pada variabel aktivitas fisik ibu hamil didapatkan ibu hamil yang obesitas dengan aktivitas sehari-hari yaitu aktivitas ringan 
sebanyak 31 orang $(81,6 \%)$, sesuai dengan teori yang ada bahwa obesitas dapat terjadi bukan hanya karena makan yang berlebihan, tetapi juga karena aktivitas fisik yang berkurang sehingga terjadi kelebihan energi. Beberapa hal yang mempengaruhi berkurangnya aktivitas fisik antara lain adanya berbagai fasilitas yang memberikan berbagai kemudahan yang menyebabkan aktivitas fisik menurun. ${ }^{4}$ Terdapat 14 orang (36,8\%) yang mengetahui tentang obesitas dan terdapat 24 orang $(63,2 \%)$ yang tidak mengetahui tentang obesitas' sedangkan semua ibu hamil (100\%) didapatkan mengetahui pengetahuan tentang gula darah.

Selama dalam kandungan, janin bergantung pada kadar glukosa dari ibu yang ditransfer melalui plasenta. Sebelum kelahiran, fetus memperoleh hampir semua energi dan glukosa dari ibu. Setelah lahir, jumlah glukosa yang disimpan hanya cukup menyuplai untuk kebutuhan beberapa jam saja, maka bayi harus menjaga kadar gula darah dengan memproduksi dan mengatur suplai glukosa sendiri. ${ }^{2,10}$

Berdasarkan penelitian, pada variabel jenis kelamin dari 38 responden bahwa mayoritas pada penelitian ini yaitu laki-laki (60,5\%), sesuai dengan penelitian menurut Lady di RS. Peshawar yaitu hipoglikemia sering pada laki-laki. Pada variabel berat badan didapatkan sebagian besar adalah bayi dengan berat badan antara 3100 sampai 3500 (36,8\%). Namun penelitian ini tidak bermakna pada bayi dengan berat badan normal karena menurut Gutberlet dan Cornblath di Amerika melaporkan bahwa frekuensi hipoglikema 4,4 per 1000 kelahiran hidup dan 15,5 per 1000 kelahiran pada berat badan lahir rendah (BBLR).

Dari hasil peneilitian didapat rerata kadar gula darah pada responden yaitu hipoglikemia, tetapi berdasarkan hasil analisa data statistika melalui uji korelasi koefisien Pearson tidak terdapat hubungan yang bermakna antara obesitas dan kadar gula darah.

\section{SIMPULAN}

Dari hasil penelitian yang dilakukan diperoleh 2 simpulan yang berbeda. Berdasarkan teori, didapatkan $\mathrm{H} 1$ yaitu ada hubungan antara semua ibu hamil yang mengalami obesitas dengan kadar gula darah yang rendah pada bayi baru lahir. Sedangkan, berdasarkan uji statistika, didapatkan $\mathrm{H} 0$ yaitu tidak terdapat hubungan yang bermakna antara kadar gula darah bayi baru lahir dengan ibu yang mengalami obesitas.

Kelemahan dan keterbatasan dari penelitian ini, antara lain hanya memeriksa kadar gula darah bayi menggunakan glukometer. Dianjurkan untuk melakukan penelitian serupa dengan pemeriksaan kadar gula darah di laboraturium.

\section{DAFTAR PUSTAKA}

1. Dorland WAN. Kamus kedokteran dorland. Edisi ke-31. Indonesian: Elsirvier; 2007. h. 923,1036,1051.

2. Azlin E. Hubungan antara skor apgar dengan kadar glukosa pada bayi baru lahir. Sari Pediatri. 2011;13:174-5.

3. Sartika RA. Faktor risiko obesitas pada anak 5-15 tahun di Indonesia. Makara kesehatan. 2011;15:37-43.

4. Sugondo S. Obesitas. In: Setiati S, Alwi I, Sudoyo AW, K Simadibrata, Setiyohadi B, Syam AF, editors. Ilmu penyakit dalam. Edisi ke-6. Jakarta: Internal Publishing; 2014. h. 2563-6.

5. Cunningham FG, Leveno KJ, Bloom SL, Hauth SL, Rouse DJ, Spong CY. Obstetric William. Edisi ke-23. Jakarta: EGC; 2009. h. 998-1005.

6. Sudirtayasa W. Obesitas dalam kehamilan. 2014 [Diakses 2015 Sept 23]. Diunduh dari: http://download.portalgaruda.org/

7. Clugston GA, Smith TE. Global nutrition problems and novel foods. 
Asia Pacific J Clin Nutr. 2002;11:100-

11.

8. Murray RK, Granne Dk, Mayes PA, Rodwell VW. Biokimia Harper. Edisi ke-25. Jakarta: EGC; $200 . \quad$ h. 119,159,180-3.

9. Sacher RA, McPherson RA. Kimia umum. Pendit BU, Wulandari, alih bahasa. Dalam:Hartanto $\mathrm{H}$, editor. Tinjauan klinis hasil pemeriksaan laboraturium. Edisi ke-11. Jakarta: EGC; 2002. h. 289-90.

10. Cranmer H, Shannon $\mathbf{M}$. Hypoglycemia. 2009 [Diakses 2015 Sept 23]. Diunduh dari: http://emedicine.medscape.com/article/ 802334-overview 